\title{
Pengetahuan Remaja terhadap Perilaku Seksual Pranikah
}

\author{
Pati Lestari, Eka Adithia Pratiwi, Indah Wasliah
}

STIKES Yarsi Mataram, NTB

\begin{tabular}{|c|c|}
\hline $\begin{array}{c}\text { Info } \\
\text { Artikel }\end{array}$ & Abstrak \\
\hline \multirow[t]{3}{*}{$\begin{array}{l}\text { Accepted: } \\
3 \text { Oktober } \\
2019\end{array}$} & $\begin{array}{l}\text { Hasil survei Program Kependudukan dan Keluarga Berencana Indonesia (BKKBN) pada tahun } 2013 \\
\text { menunjukkan bahwa lebih dari } 60 \% \text { remaja di Indonesia telah melakukan hubungan seks pranikah. } \\
\text { Ada sekitar 53\% wanita berusia 10-19 tahun melakukan hubungan seksual pada masa remaja } \\
\text { sedangkan jumlah pria yang melakukan hubungan seksual lebih dari dua kali lipat daripada wanita. } \\
\text { Tujuan penelitian: Penelitian ini bertujuan untuk mengetahui korelasi pengetahuan remaja terhadap } \\
\text { perilaku seksual yang belum menikah di Sekolah Menengah Kejuruan Negeri } 1 \text { Tarano Sumbawa } \\
\text { 2018. Metodologi: Desain penelitian yang digunakan dalam penelitian ini adalah desain analitik } \\
\text { observasional dengan desain penelitian cross sectional dengan jumlah sampel dalam Penelitian ini } \\
\text { sekitar } 79 \text { responden. Teknik pengambilan sampel yang digunakan dalam penelitian ini adalah Simple } \\
\text { random sampling. Instrumen pengumpulan data yang digunakan dalam penelitian ini adalah kuesioner. } \\
\text { Kesimpulan: Analisis data menggunakan uji Chi Square. Hasil uji statistik diperoleh nilai signifikansi } \\
\text { 0,004 (p <0,05), dapat disimpulkan bahwa Ho ditolak (ada hubungan bermakna pengetahuan remaja } \\
\text { terhadap perilaku seksual yang belum menikah di Sekolah Menengah Kejuruan Negeri } 1 \text { Tarano } \\
\text { Sumbawa 2018). Rekomendasi yang dapat diberikan adalah kepada pembaca adalah memberikan } \\
\text { pendidikan kesehatan tentang perilaku seksual yang belum menikah, guna mencegah perilaku seksual } \\
\text { yang belum menikah.Kata Kunci: kekerasananak, usiasekolah, verbal abuse }\end{array}$ \\
\hline & $\begin{array}{c}\text { Kata kunci : pelecehan anak, usia sekolah, anak-anak, pelecehan verbal } \\
\text { Knowledge on Adolescent Sexual Behavior Premarital } \\
\text { Abstract }\end{array}$ \\
\hline & $\begin{array}{l}\text { The survey results of the Indonesian Population and Family Planning Program (BKKBN) in } 2013 \\
\text { showed that more than } 60 \% \text { of teenagers in Indonesia have had premarital sex. There are } \\
\text { approximately 53\% of women aged } 10 \text {-19 years of sexual intercourse in adolescence while the number } \\
\text { of men who have sexual intercourse more than doubled than women. This research aims to determine } \\
\text { the correlation of adolescent knowledge toward unmarried sexual behavior in State Vocational High } \\
\text { School } 1 \text { Tarano Sumbawa 2018. The research design used in this research is an observational } \\
\text { analytic design with cross sectional research design with total samples in this research around } 79 \\
\text { respondents. Technique of sampling used in this research is Simple random sampling. The instruments } \\
\text { of data collection used in this research is questionnaire. Data analysis using Chi Square test. Result of } \\
\text { statistical test obtained significance value of } 0.004 \text { (p <0.05), it can concluded that Ho is rejected } \\
\text { (there is a meaningful correlation of adolescent knowledge toward unmarried sexual behavior in State } \\
\text { Vocational High School } 1 \text { Tarano Sumbawa 2018). The recommendations can be given is to readers is } \\
\text { provide of health education about unmarried sexualbehavior, in order to prevent the unmarried sexual } \\
\text { behavior. }\end{array}$ \\
\hline
\end{tabular}

Corresponding author:

Eka Adithia Pratiwi

pratiwiekaadithia@gmail.com

Jurnal Ilmu Keperawatan Anak, Vol ........No ........, ............ 201...

DOI: 


\section{PENDAHULUAN}

Menurut who 2012, remaja adalah penduduk dalam rentang usia 10-19 tahun. Menurut peraturan menteri kesehatan ri nomor 25 tahun 2014. Remaja adalah penduduk dalam rentang usia 10-18 tahun. Menurut badan kependudukan dan keluarga berencan nasional (bkkbn) rentang usia remaja adalah 10-24 tahun dan belum menikah (who, 2014). Masa remaja sering di artikan dengan masa transisi dari anakanakmenuju dewasa. Masa ini merupakan periode persiapan menuju masa dewasayang akan melewati beberapa tahapan perkembangan penting dalam hidup. Selain kematangan fisik dan seksual, remaja juga mengalami tahapan menuju kemandirian sosial dan ekonomi, membangun identitas, akuisisi kemampuan (skill) untuk kehidupan masa dewasa serta kemampuan bernegosiasi (abstract reasoning) (who, 2015).

Berdasarkan data badan pusat statistik (bps) perempuan yang menikah sebelum usia 18 tahun di indonesia pada tahun 2013-2015 sebanyak 22,8\%, kemudian pada tahun 2015-2017 mengalami kenaikan sebanyak 2,9\% menjadi $25,7 \%$. Data kpai (komisi perlindungan anak indonesia) pada tahun 2014 terdapat 4 kasus, pada tahun 2015 terdapat 7 kasus dan meningkat pada tahun 2016 sebanyak 10 kasus. Badan kependudukan dan keluarga berencana nasioanal (bkkbn) nusa tenggara barat (ntb) (2016) tercatat sekitar 51\% pernikahan dini terjadi di wilayah ntb. Berdasarkan data kpai (komisi perlindungan anak indonesia) 2016, anak korban tayangan dan pergaulan bebas meningkat di dua tahun terakhir, pada tahun 2014 sebanyak 64 kasus, 2015 sebanyak 113 kasus, dan pada tahun 2016 meningkat sebanyak 157 kasus dan anak sebagai pelaku aborsi meningkat pada tahun 2015 sebanyak 19 kasus meningkat pada tahun 2016 sebanyak 33 kasus.

Hasil survey bkkbn menunjukkan bahwa lebih dari $60 \%$ remaja di indonesia telah melakukan hubungan seks pranikah (saftia, 2013). Di laporkan bahwa 80\% remaja laki-laki dan $70 \%$ remaja perempuan melakukan hubungan seksual selama masapubertas dan $20 \%$ dari mereka mempunyai empat atau lebih pasanga. Ada sekitar 53\% perempuan berumur 10-19 tahun melakukan hubungan seksual pada masa remaja sedangkan jumlah laki-laki yang melakukan hubungan seksual sebnayak dua kali lipat dari pada perempuan.

Pada masa remaja terjadi perubahan fisik dan seksual yang signifikan sehingga ketertarikan seksual terhadap lawan jenis cukup besar dan dorongan seksual juga berkembang. Perubahan fisik yang pesat dan perubahan hormonal merupakan pemicu masalah kesehatan remaja serius karena timbulnya dorongan motivasi seksual yang menjadikan remaja rawan terhadap penyakit dan masalah kesehatan reproduksi (kespro), kehamilan remaja dengan segala konsekuensinya yaitu hubungan seks pranikah, aborsi, penyakit menular seksual (pms), hivaids serta narkotika (margaretha, 2012).

Salah satu faktor penyebab terjadinya penyimpangan perilaku seksual pada remaja yaitu pengetahuan. Kurangnya pemahaman tentang perilaku seksual pada remaja amat merugikan bagi remaja sendiri termasuk keluarganya, adapun faktor-faktor yang mempengaruhi perilaku seksual pranikah yaitu antara lain hubungan orang tua, tekanan negatif teman sebaya, eksposur media pornografi, serta media informasi seperti paparan media massa baik cetak (koran, majalah, buku-buku 
porno) maupun elektronik (tv, vcd, internet) mempunyai pengaruh secara langsung maupun tidak langsungpada remaja untuk melakukan hubungan seksual pranikah (qomarasari, desy. 2015).

Remaja tanpa pengetahuan yang memadai mengenai resiko-resiko seksual pranikah mudah terjebak dalam penggunaan narkoba atau melakukan hubungan seks yang beresiko seperti hubungan seks dengan pasangan berganti-ganti atau hubungan seks tanpa perlindungan.resiko dari perilaku seksual tersebut sangat luas, tidak hanya mengancam mereka secara fisik tetapi juga secara psikologis dan sosial. Resiko fisik seperti penularan berbagai pms (penyakit menular seksual) sampai dengan hiv/aids (human immunodeficiency virus/ acqiured immuno deficiency syndrom), kehamilan pada usia dini, melahirkan usia dini, aborsi tak aman, resiko psikologis dan sosial seperti trauma, kehilangan berbagai hak, dan sebagainya. Resiko dari perilaku remaja ini tidak hanya berakibat jangka pendek, bahkan dapat mempengaruhi kelanjutan hidup remaja itu seterusnya (irianto, 2014).

\begin{abstract}
METODE
Jenis penelitian yang digunakan dalam penelitian ini adalah korelasidengan pendekatan cross sectional study. sampel dalam penelitian ini adalah siswa/siswi kelas $\mathrm{x}$ dan $\mathrm{xi}$ jurusan agribisnis tanaman pangan dan hultikultural, agribisnis ternak ruminansia, rekayasa perangkat lunak, teknik komputer jaringan, dan teknik sepeda motor yaitu sebanyak 79 responden, dimana teknik pengambilan sampel dengan menggunakan simpel random sampling
\end{abstract}

\section{HASIL}

Jenis penelitian yang digunakan dalam penelitian ini adalah korelasidengan pendekatan cross sectional study. sampel dalam penelitian ini adalah siswa/siswi kelas $\mathrm{x}$ dan $\mathrm{xi}$ jurusan agribisnis tanaman pangan dan hultikultural, agribisnis ternak ruminansia, rekayasa perangkat lunak, teknik komputer jaringan, dan teknik sepeda motor yaitu sebanyak 79 responden, dimana teknik pengambilan sampel dengan menggunakan simpel random sampling

Tabel 1.

Distribusi responden berdasarkan umur $(n=79)$

\begin{tabular}{ccc}
\hline Umur & $\mathrm{f}$ & $\%$ \\
\hline 16 tahun & 19 & 24.1 \\
17 tahun & 47 & 59.5 \\
18 tahun & 12 & 15.2 \\
19 tahun & 1 & 1.3 \\
\hline
\end{tabular}

Berdasarkan tabel diatas, di dapatkan hasil responden terbanyak adalah umur $(59.5 \%)$ dan paling sedikit adalah usia 19 tahun sebanyak 1 responden (1.3\%)

17 tahun sebanyak 47 responden

Tabel 2.

Distribusi responden berdasarkan jenis kelamin

\begin{tabular}{ccc}
\hline Jenis Kelamin & $\mathrm{f}$ & $\%$ \\
\hline Perempuan & 35 & 44.3 \\
Laki-Laki & 44 & 55.7 \\
\hline
\end{tabular}


Berdasarkan tabel diatas didapatkan laki-laki sebanyak 44responden(55.7\%). jumlah responden terbanyak adalah

Tabel 3. Distribusi frekuensi jenis perolehan informasi $(n=79)$

\begin{tabular}{|c|c|c|}
\hline Perolehan Informasi & $\mathrm{f}$ & $\%$ \\
\hline Tenaga kesehatan & 4 & 5.1 \\
\hline Media elektronik & 46 & 58.2 \\
\hline Belum Pernah & 29 & 36.7 \\
\hline $\begin{array}{l}\text { Berdasarkan tabel di atas di dapatkan } \\
\text { bahwa perolehan informasi di dapat dari }\end{array}$ & & $\begin{array}{l}\text { dan yang paling } \\
\text { kesehatan yaitu }\end{array}$ \\
\hline
\end{tabular}

Tabel 4.

Distribusi responden berdasarkan pengetahuan $(n=79)$

\begin{tabular}{lcc}
\hline \multicolumn{1}{c}{ Pengetahuan } & f & $\%$ \\
\hline Baik & 29 & 36.7 \\
Cukup & 32 & 40.5 \\
Kurang & 18 & 22.8 \\
\hline Tabel diatas dapat dilihat bahwa paling & \multicolumn{2}{c}{ responden (40,5\%) dan paling sedikit } \\
banyak remaja mempunyai pengetahuan & & remaja dengan pengetahuan kurang yaitu \\
yang cukup yaitu sebanyak 32 & & sebanyak 18 responden $(22,8 \%)$.
\end{tabular}

Tabel5.

Distribusi responden berdasarkan perilaku seksual pranikah $(\mathrm{n}=79)$

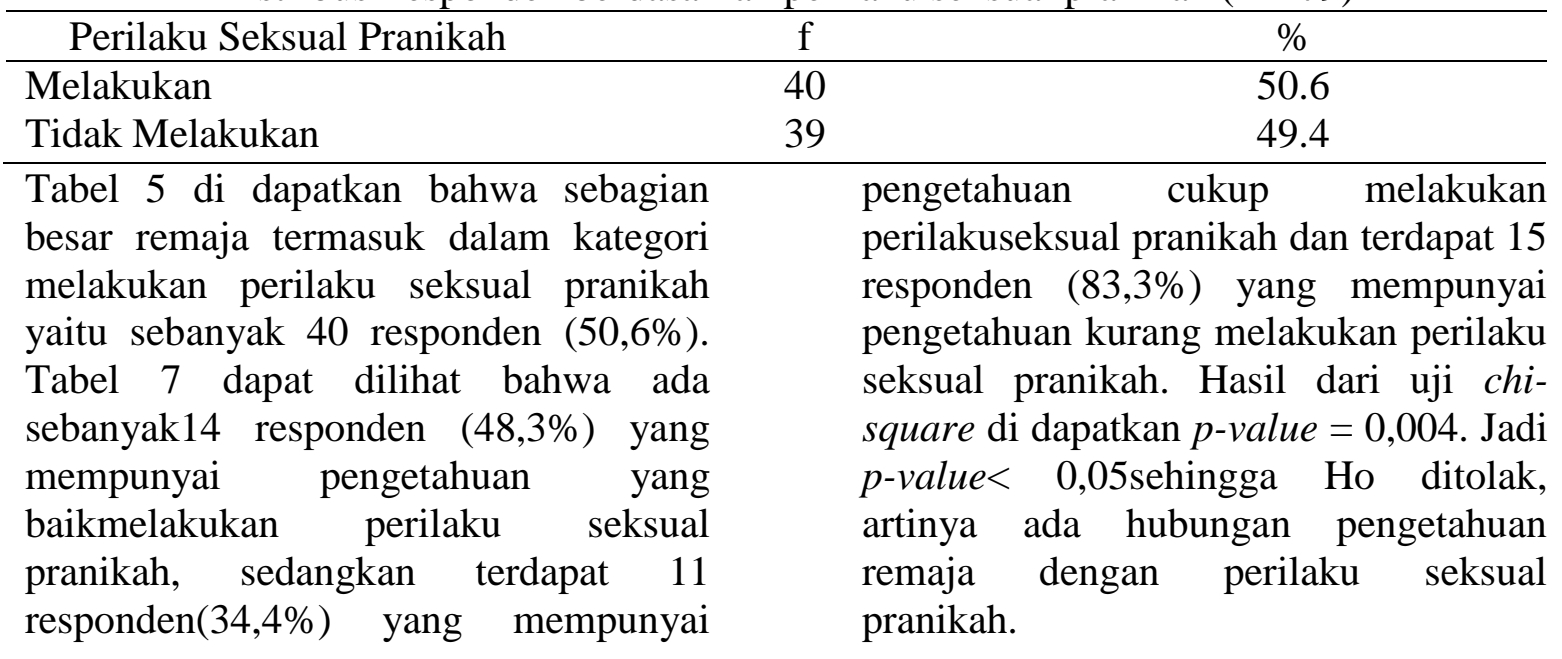

Tabel 6.

Pengetahuan remaja dengan perilaku seksual pranikah $(n=79)$

\begin{tabular}{lccccccc}
\hline $\begin{array}{l}\text { Penge- } \\
\text { tahuan }\end{array}$ & \multicolumn{3}{c}{ Perilaku Seks Pra Nikah } & \multicolumn{2}{c}{ Total } & P-Value \\
& $\begin{array}{c}\text { Melakukan } \\
\text { f }\end{array}$ & $\%$ & Tidka Melakukan & & & \\
\hline Baik & 14 & 17.7 & 15 & 19.0 & 29 & 36.7 & 0.004 \\
Cukup & 11 & 13.9 & 21 & 26.6 & 32 & 40.5 & \\
Kurang & 15 & 19 & 3 & 3.8 & 18 & 22.8 & \\
\hline
\end{tabular}

Eka Adithia Pratiwi - Pengaruh Edukasi melalui Media Video terhadap Pengetahuan dan Sikap Keluarga tentang Pneumonia pada Balita 


\section{PEMBAHASAN}

Berdasarkan hasil penelitian ini menunjukkan bahwa paling banyakremaja mempunyai pengetahuan yang cukup yaitu sebanyak 32 responden(40,5\%) sedangkan remaja yang mempunyai pengetahuan yang baiksebanyak 29 responden $(36,7 \%)$, dan remaja yang mempunyai pengetahuankurang yaitu sebanyak 18 responden $(22,8 \%)$. Berdasarkan hasil penelitian ini menunjukkan bahwa sebagian besarremaja termasuk dalam kategori melakukan perilaku seksual pranikah yaitusebanyak 40 responden $(50,6 \%)$, sedangkan remaja yang tidak melakukanperilaku seksual pranikah sebanyak 39 responden $(49,4 \%)$.

Berdasarkan uji statistik yang dilakukan dengan menggunakan ujichi-square di dapatkan $p$-value $=0,004$. Jadi $p$-value $<$ 0,05 sehingga Hoditolak, artinya ada hubungan pengetahuan remaja dengan perilaku seksual pranikah pada siswa/siswi SMK Negeri 1 Tarano tahun 2018. Salah satu faktor penyebab terjadinya perilaku seksual pada remajayaitu pengetahuan.Kurangnya pemahaman tentang perilaku seksual padaremaja amat merugikan bagi remaja sendiri termasuk keluarganya. Hal inisesuai dengan pernyataan Notoatmodjo (2007) bahwa pengetahuan merupakan domain yang penting untuk membentuk suatu sikap yang utuhdan pengetahuan yang tinggi akan membentuk perilaku yang baik, sebaliknya pengetahuan yang rendah akan membentuk perilaku yang buruk.

Menurut Sarwono (2011) Selain dari faktor pengetahuan masihbanyak lagi faktor yang mempengaruhi terjadinya perilaku seksual pranikahyaitu faktor internal meliputi perubahan-perubahan hormonal yangmeningkatkan hasrat seksual yang membutuhkan penyaluran dalam bentuktingkah laku seksual tertentu dan faktor eksternal seperti pengaruh temansebaya, peran keluarga, media informasi, lingkungan pergaulan, pendidikan,sosial ekonomi, adanya peluang, pengaruh norma budaya dari luar dan lainsebagainya sehingga walaupun seseorang memiliki pengetahuan yang baikbelum tentu pula memiliki perilaku yang baik.

Pernyataan diatas sejalan dengan penelitian yang dilakukan olehMaryatun (2012), dengan hasil penelitian dalam kategori pengetahuan baikmelakukan perilaku seksual pranikah sebanyak 27 responden $(51,9 \%)$ dantidak melakukan sebanyak 25 responden $\quad(48,1 \%) \quad$ sedangkan kategoripengetahuan kurang baik melakukan perilaku seksual pranikah sebanyak 43responden $(82,7 \%)$ dan tidak melakukan sebanyak 9 responden $(17,3 \%)$.Hasil analisa p-value sebesar 0,02 dengan OR sebesar 4,424 (1,79710.894)yang mempunyai makna bahwa terdapat hubungan signifikan antarapengetahuan dengan perilaku seksual pranikah pada anak jalanan. Fenomena yang terjadi di lapangan seiring dengan semakinmeningkatnya arus teknologi sehingga begitu mudahnya remaja untukmengakses internet secara leluasa dan bebas. Informasi yang semakin bebasmelalui berbagai media massa menjadikan perilaku dan gaya hidup remajayang semakin mengarah pada budaya barat, apalagi dengan maraknyaadegan pornografi dari berbagai macam media informasi.

Kemajuanteknologi sering juga disalahgunakaan oleh orang tua, kemajuan teknologidi jadikan ajang untuk pamer bahwa mereka mampu untuk memfasilitasianaknya seperti orang tua lainnya. Mereka terlalu menuruti kemauan anak-anaknya maupun remaja, memfasilitasi mereka dengan hal-hal digital seperti handphone tanpa pengawasan berkelanjutan. Longgarnya pemantauan serta persepsi orang tua terhadap masalah seksualitas, ketidaktahuan orang tua yang masih 
menabuhkan pembicaraan seksual dengan anak maupun remaja cendrung membuat jarak diantara mereka,padahal peran orang tua sangatlah penting dalam hal tersebut.

Selain dari hal di atas tekanan dari teman sebaya juga mempengaruhi maraknya perilaku seksual pranikah di lingkungan pergaulan. Keinginan untuk dapat diterima oleh lingkungan pergaulan remaja begitu besar,sehingga dapat mengalahkan norma dan nilai-nilai yang ada. Pada umumnya remaja tersebut melakukan perilaku seksual pranikah hanyasebatas ingin membuktikan bahwa dirinya sama dengan teman-temannya,sehingga dapat diterima menjadi anggota kelompoknya seperti yang diinginkan.

Adanya tekanan dari pacar juga ikut memberi sumbangsihterhadap terjadinya perilaku seksual pranikah dikarenakan kebutuhanseseorang untuk mencintai dan dicintai, seseorang harus rela melakukan apasaja terhadap pasangannya untuk membuktikan keseriusannya tanpamemikirkan resiko yang nanti dihadapi. Perekonomian yang semakin majujuga memberi dampak kepada oarangorang yang perekonomian menengah kebawah. Kemiskinan mendorong terbentuknya kesempatan bagi remajakhususnya wanita untuk melakukan perilaku seksual pranikah.

Pada usia remaja khususnya pada remaja menengah (middle adolescent) Terjadinya perubahan hormonal yang meningkatkan hasratseksual (libido seksual) sehingga remaja membutuhkan penyaluran dalambentuk tingkah laku tertentu. Penyaluran ini tidak dapat segera dilakukan karena adanya penundaan usia perkawinan. Selanjutnya remaja akanberkembang lebih jauh terhadap hasrat seksual kepada tingkah laku yanglebih seperti berpegangan tangan, berciuman, sampai dengan bersenggama.

Kecendrungan semakin meningkat oleh karen adanya penyebaran informasidan ransangan seksual melalui media massa yang dengan adanya teknologicanggih (vidio, VCD, telepon, internet dan lainlain) menjadi tidakterbendungnya lagi yang sedang dalam periode ingin tahu dan inginmencoba tindakan perilaku seksual. Pengetahuan remaja yang kurang mengetahui tentang penyimpangan perilaku seksual maka sangatlahmungkin jika membuat mereka salah dalam bersikap dan kemudian mempunyai perilaku terhadap seksualitas (Sarwono, 2011).

Berdasarkan penelitian yang dilakukan oleh Arum (2015) menunjukkan analisis statistik menggunakan uji chi square, ada hubungan yang signifikan antara pengetahuan $(p$-value $=0,004)$ dan jenis kelamin $(p$-value $=0,003)$ dengan perilaku seksual pranikah. Remaja tanpa pengetahuanyang memadai mengenai resiko-resiko seksual pranikah mudah terjebakdalam penggunaan narkoba atau melakukan hubungan seks yang beresikoseperti hubungan seks dengan pasangan berganti-ganti atau hubungan sekstanpa perlindungan.Resiko dari perilaku seksual tersebut sangat luas, tidakhanya mengancam mereka secara fisik tetapi juga secara psikologis dansosial.

Resiko fisik seperti penularan berbagai PMS (Penyakit MenularSeksual) sampai dengan HIV/AIDS (Human Immunodeficiency Virus/Acqiured Immuno Deficiency Syndrom), kehamilan pada usia dini,melahirkan usia dini, aborsi tak aman, resiko psikologis dan sosial sepertitrauma, kehilangan berbagai hak, dan sebagainya. Resiko dari perilaku remaja initidak hanya berakibat jangka pendek, bahkan dapat mempengaruhi kelanjutan hidup remaja itu seterusnya (irianto, 2014).

Remaja yang mempunyai tingkat pengetahuan yang tinggi tentangseksual maka mereka akan cenderung mempunyai perilaku yang positifterhadap seksual pranikah. Sebaliknya remaja yang tingkat pengetahuanyang rendah tentang seksual

Eka Adithia Pratiwi - Pengaruh Edukasi melalui Media Video terhadap Pengetahuan dan Sikap Keluarga tentang Pneumonia pada Balita 
maka mereka cenderung akan berperilakunegatif terhadap seksual pranikah. Penelitian Tina dan Sari (2010) juga menyatakan hal yang serupa, semakin baik tingkat pengetahuan makasemakin baik sikapnyaterhadapsesuatuhal,semakin kurang pengetahuannya semakin negatif sikapnya terhadap sesuatu hal.

\section{SIMPULAN}

Hasil penelitian menunjukkan bahwa Pengetahuan remajaterhadap perilaku seksual pranikah termasuk dalam kategori cukup.Perilaku seksual pranikah ditermasuk dalam kategorimelakukan perilaku seksual pranikah. Ada hubungan yang signifikan antarapengetahuan remaja dengan perilaku seksual pranikah pada siswa/siswi SMKNegeri 1 Tarano Sumbawa Besar tahun 2018 dengan hasil dari uji chi-squaredi dapatkan $p$-value $=$ 0,04 . Jadi $p$-value 0,05 sehingga Ho ditolak dan Haditerima.

\section{REFERENSI}

Dianawati, A (2006). Pendidikan Seks Untuk Remaja. Jakarta: Kawan Pustaka

Fitriani (2011).Hubungan Pendidikan Seks dengan Perilaku seksual pada Remajadi SMK PRAYATNA-1 Medan. Karya Tulis Ilmiah D-IV BidanPendidik Fakultas Keperawatan Universitas Sumatera Utara.

Harni, Andriani, dkk (2016).Hubungan Pengetahuan Akses Media Informasi DanPeran Keluarga Terhadap Perilaku Seksual Pada Siswa SMK N 1Kendari. Vol.VIII, No.1 (1-11)

Herlina (2015).Faktor-Faktor yang Berhubungan Dengan Perilaku SeksPranikah Pada Remaja Putri Di SMAN 2 Kota Jambi. Vol.4, No.2(174-180).
Agus (2013).Kapita Selekta Kuesioner Pengetahuan dan Sikap Dalam penelitianKesehatan.Jakarta : Salemba Medika

Ali \& Asrori (2012). Psikologi Remaja Perkembangan Peserta Didik. Jakarta: PT.Bumi Aksara

Arikunto, S (2010). Prosedur Penelitian : Suatu Pendekatan Praktik. (EdisiRevisi). Jakarta: Rhineka Cipta

Hastono, Susanto Priyo (2007).Analisis Data Kesehatan. Depok: FakultasKesehatan Masyarakat, Universitas Indonesia.

Hurlock, B Elizabeth (1964).Child Development. New York. Mc. Graw HillBook Company. Inc

Intan \& Iwan ( 2012).Kesehatan Reproduksi untuk Mahasiswa Kebidanan danKeperawatan. Jakarta: Salemba Medika

Irianto (2014). Seksologi Kesehatan. Bandung: Alfabeta

Jayanti (2010).Konsep Perilaku Seksual Pra

Nikah.http//www.dwixhykaru.diakses pada tanggal 01 Januari 2018, jam 16.00 WITA

Kusmiran, E (2013).Kesehatan Reproduksi Remaja dan Wanita. SalembaMedika: Jakarta

Martharina (2013).Hidup Sehat dengan Menjaga Pergaulan. Jakarta: RhinekaCipta

Notoatmodjo, S (2010). Metodologi Penelitian Kesehatan. Jakarta: PT. RhinekaCipta

Nursalam (2011).Konsep dan Penerapan Metodologi Penelitian IlmuKeperawatan. Jakarta: Salemba Medika. 
Paul B. Horton-Chester L. Hunt (1996).Sosiologi. PT. Gelora Aksara Pratama

Pieter, H. Z (2012).Pengantar Komunikasi dan Konseling Dalam PraktikKebidanan.Suatu Kajian psikologi. Jakarta: Kencana Prenada MediaGroup

Pinem, Saroha (2009).Kesehatan Reproduksi dan Kontrasepsi.Jakarta: TransInfo Media

Qomarasari, Desy (2015). Hubungan Antara Peran Keluarga, Sekolah, TemanSebaya, Pendapatan Keluarga, Media Informasi dan Norma Agamadengan Perilaku Seksual Remaja SMA di Surakarta.Tesis. FakultasKesehatan Masyarakat. Universitas Sebelas Maret. Surakarta.

Riyanto, A (2011). Aplikasi Metodologi Penelitian Kesehatan. Yogyakarta : NuhaMedika

Sarwono, S. W (2007). Psikologi Remaja.Jakarta : PT. Rajagrafindo Persada

Setiadi (2007).Konsep dan Penulisan Riset Keperawatan. Yogyakarta: GrahavIlmu

Soetjiningsih (2004).Tumbuh Kembang Remaja dan Permasalahannya.Jalarta :PT. Rhineka Cipta

Sofyan (2012).Remaja dan Masalahnya.Bandung : Alfa Beta

Sugiyono (2010). Metode Penelitian Kualitatif dan Kuantitatif dan $R$ \& D.Bandung : Alfa beta 